\title{
In Search of a Better Life: The Occupational Attainment of Rural and Urban Migrants in China
}

\begin{abstract}
This paper investigates the occupational attainment and job mobility of permanent ruralto-urban migrants and compares them with migrants who were born with an urban hukou. We examine how much of the gap in occupational-prestige scores between rural-to-urban and urban-to-urban migrants can be explained by differences in observable characteristics up to the time of migration. With controls for these characteristics, the difference in occupational attainment between rural and urban migrants becomes statistically insignificant or even positive for some subgroups. In contrast, job mobility analysis reveals that rural migrants are generally more mobile and also more likely to move to better jobs by changing work units, whereas urban migrants are more likely to be promoted within a work unit.
\end{abstract}

JEL-codes: O15, J0, J61, J62

Keywords: internal migration, China, job mobility, occupational prestige, hukou

\section{Introduction}

A substantial body of literature on China's internal migration has shown that hukou (household registration system) status has increased wage inequality and occupational segregation between individuals who have always resided in urban areas (hereafter, urban residents) and individuals who migrated from rural areas to urban areas (hereafter, rural-tourban migrants; Liu 2005; Lu and Song 2006; Meng and Zhang 2001; Zhang and Wu 2012) . In the 1980s the Chinese government began to give permission to individuals to live and work outside of their places of hukou registration to encourage farmers to migrate to urban 
areas to meet the rapidly growing labor demand in China's cities. Removing the migration restriction sharply increased the number of temporary rural-to-urban migrants (migrants to urban areas who retain their rural hukou), who comprised 75 percent of the internal migrants in China in 2000 (Liang and Ma 2004). ${ }^{1}$ Additionally, a sequence of hukou policy reforms during the 1980s and 1990s enabled a greater number of rural-to-urban migrants to obtain a permanent urban hukou (i.e., permanent rural-to-urban migrants). ${ }^{2}$ According to Deng and Gustaffson (2006), permanent rural-to-urban migrants made up 20.3 percent of China's urban populations in 2002. Nevertheless, the increasing numbers of permanent rural-to-urban migrants and their assimilation into the urban labor market have not been studied much in the literature.

Whereas previous studies on Chinese internal migrants have focused on temporary migration, this paper fills a gap in the literature by examining permanent migrants who change their hukou status. In particular, this study explores the occupational attainment and job mobility of rural-to-urban migrants who successfully obtained a local urban $h u k o u .{ }^{3} \mathrm{~A}$ better understanding of permanent rural-to-urban migrants and their occupational attainment will shed light on how hukou policy might affect the labor-market performance of the temporary rural-to-urban migrants (i.e. floating population). Furthermore, while sociologists have examined the hukou mobility of rural-to-urban migrants (Wu and Treiman 2004; Zhang and Treiman 2013; Zhang and Wu 2012), no studies have covered urban-to-urban migration. We specifically compare permanent rural-to-urban migrants with urban-to-urban migrants who were born with a hukou from a city other than where they resided at the time of data collection. Both groups are permanent migrants, and most of them had obtained a hukou registration in the destination city by the time of survey (although not necessarily at the same time as their relocation to the destination city). Comparing these two groups sheds light on whether an individual's original hukou type affects the rate of assimilation in urban areas. 
Furthermore, we restrict the analysis to migrants who were employed prior to migrating to understand changes in occupational attainment and how accumulated skills or prior experiences might affect post-migration labor market outcomes. ${ }^{4}$

We focus on occupational-prestige scores and job mobility as proxies of assimilation in destination cities for both groups of migrants. Specifically, using retrospective employment and migration histories from the Chinese General Social Survey (CGSS) in 2003, we construct panel data of occupational-prestige scores ${ }^{5}$ based on the average educational attainment of workers employed in each occupation to capture additional, less tangible job features such as welfare and social status. We also examine how much of the gap between rural-to-urban and urban-to-urban migrants can be explained by differences in observable characteristics such as education, parental background, and premigration job characteristics. Furthermore, we explore migrants' job mobility to understand the evolution

of their performance and opportunities in the urban labor market. We consider changes within the work unit and changes between work units for both migrant groups and associate them with changes in the occupational-prestige scores.

The paper is arranged as follows. The next section summarizes the relevant literature. We then describe our data and our empirical strategies, followed by a section that reports the main findings. In the last section we conclude with policy implications.

\section{Background}

\section{Hukou and internal migration}

The hukou system in China, which was established in the late 1950s, requires every member of the household to register at the local authority of their permanent residence (Chan and Bukingham 2008). For several decades the system placed strict limitations on migration, but these restrictions were later relaxed in the late 1970s. The dual classification of hukou 
registration is based on both the place and status (i.e., type) of the person's regular residence (Chan and Bukingham 2008; Chan and Zhang 1999). The type can be either agricultural or nonagricultural. Most agricultural-hukou holders reside in rural areas; therefore, they are also known as rural-hukou holders. Nonagricultural-hukou holders are often called urban-hukou holders because they mostly reside in urban areas. Very limited state socioeconomic benefits were given to the rural-hukou population, and the state utilized the hukou system to impose significant limits on Chinese citizens' geographical mobility (Wu and Treiman 2004; Zhao and Liu 1997). Because hukou status was tied to access to food, education, health services, and other basic necessities in the system's early years, it was very rare or even impossible for people to live in a place outside their hukou registration (Fan 2002a) until the hukou reform in the late 1970s. Transferring a rural hukou to an urban hukou (known as nong-zhuan-fei in Chinese) requires state approval. There are various restrictions (Chan and Bukingham 2008; Wu and Treiman 2004; Zheng and Wu 2012) to making a transfer, and this process was more difficult to navigate before the late 1970s. As a result, labor mobility was not very common during this time.

The hukou system was reformed several times over the following decades to help the country meet the rapidly increasing labor demand in urban cities due to the economic reforms in the late 1970s. The reforms simplified the rural-to-urban transfer process Additionally, the introduction of national ID cards and temporary residence permits in the mid-1980s induced a new wave of internal migrants (Fan 2002a) who no longer needed to register their hukou in the area where they worked or lived. These nonhukou migrants were temporary migrants without a local household registration status. ${ }^{6}$ In contrast, migrants who transferred their hukou to a local authority in the migration destination were dubbed hukou migrants or permanent migrants. The growth of rural-to-urban migrants, both temporary and permanent, has been tremendous: the number grew from 8.9 million in 1989 (Zhao 2005) to 79.7 million 
in 2005 (Gagnon, Xenogiani, and Xing 2011). Urban-to-urban migrants comprise the secondlargest group of internal migrants in China: they accounted for 4.5 percent of the total population in 2005 (Gagnon et al, 2011), which is only 1.6 percent less than the population of rural-to-urban migrants.

\section{Hukou and labor market segregation}

One effect of China's hukou system is that it leads to segregation in the urban labor market (Cai and Wang 2007; Meng and Zhang 2001; Zhang and Wu 2012). Although both education and experience play an important role in the occupational segregation between rural migrants and urban residents (Meng and Zhang 2001; Démurger et al. 2009; Gagnon et al, 2011; Zhang and Wu 2012), ${ }^{7}$ many cities have reserved some occupational categories for registered urban residents, and therefore rural residents tend to be segregated into low-skilled or unskilled jobs (e.g., low-end service and construction jobs) that are typically unwanted by urban residents(Brauw and Giles 2006). Furthermore, state-owned enterprises and those that require local hukou status tend to protect local workers and discriminate against migrants. Even in low-prestige occupations, which have relatively lower entry requirements, the protection of local workers is strong given the large number of local urban workers who have been laid off. Not surprisingly, studies that use local urban workers as a comparison group for internal migrants in China often find large discrimination and occupational-segregation effects on the earnings gap between these two groups (Zhao 2005).

Although permanent rural-to-urban migrants are likely to be positively selected compared to temporary rural-to-urban migrants and rural residents who do not migrate, their socioeconomic status is, on average, still lower than that of urban residents (Wang, Oropesa, and Firebaugh 2009; Zhang and Treiman 2013). ${ }^{8}$ Furthermore, Cai and Wang (2007) point to the source of household registration as a determining factor in various employment outcomes, 
such as obtaining formal employment. Urban-to-urban and rural-to-urban migrants, both of whom have nonlocal hukou status, face the same barriers to entering occupations and industries in the destination labor market. Even though urban-to-urban migrants hold a nonagricultural hukou (like local urban workers), they do not seem to have better occupational access than rural-to-urban migrants who hold an agricultural hukou.

To better understand how individual characteristics (e.g., level of education) affect the occupational attainment of rural-to-urban migrants, we can use urban-to-urban migrants as a comparison group. Urban-to-urban migrants are a better comparison group for rural-to-urban migrants than are local urban residents because the former two groups both tend to be viewed as outsiders by local urban residents. ${ }^{9}$ Rural-to-urban and urban-to-urban migrants differ in their original hukou type, but they both face high job-search costs and a segregated labor market that favors local urban residents, and this situation has intensified since labor reforms were enacted to protect local workers who were laid off from state-owned enterprises (Cai and Wang 2007; Zhang 2010).

Several factors help explain why the assimilation speed for rural-to-urban migrants is different than that of urban-to-urban migrants. First, skill sets that are valued in the rural labor market are less likely to fully transfer into the urban labor market or to be valued in the same way. Second, the quality of educational and job training received prior to migration is often low, which affects their assimilation in the destination city. Finally, the selectivity of rural and urban migrants might also affect assimilation speed, although this is difficult to detect.

\section{Related literature on the occupational attainment of rural migrants}

Most existing literature on China's internal migration focuses on floating populations, especially temporary rural-to-urban migrants. These studies usually use local urban residents 
or workers as a comparison group for temporary rural-to-urban migrants. Researchers have focused extensively on the earning differentials between temporary rural-to-urban migrants and local residents, including the determinants of selection into different occupational sectors. Despite substantially different data sets (Zhao 2005), all of these existing studies (Liu 2005; Lu and Song 2006) establish that wage inequality between the two groups is mainly due to the low educational attainment among the rural population and low returns to education in the rural labor market. Moreover, the unexplained wage gap between rural migrants and urban residents might be attributed to the labor market's favoritism toward urban hukou holders and discrimination against rural migrants (Lu and Song 2006; Meng and Zhang 2001). ${ }^{10}$ For example, Meng and Zhang (2001) find that discrimination within occupations can explain about 82 percent of the hourly wage differential between local urban workers and rural-tourban migrant workers.

Gagnon et al. (2011) explain the substantial differences between rural-to-urban migrants, urban-to-urban migrants, and urban residents by separating the effect of migration from the effect of hukou. Using an Oaxaca-Blinder decomposition, the authors find that as much as 40 percent of the observed wage gap between rural-to-urban and urban-to-urban migrants might be attributable to hukou status. They also compare urban-to-urban migrants with urban residents and find a large migration premium. Nevertheless, the migrants, in particular rural-to-urban migrants, face a type of labor discrimination in which formal sectors are less likely to employ them, thereby preventing them from accessing health and educational services. However, in their study, Gagnon et al. (2011) do not consider permanent rural-to-urban migrants who obtained an urban hukou.

Another paper that is closely related to ours is Deng and Gustafsson's (2006) study, which is one of the few empirical attempts to examine permanent migrants. Combining several household surveys, the authors investigate the determinants and economic benefits of 
permanent migration by comparing permanent rural-to-urban migrants with local-born urban workers, as do most other studies in the literature. They run regressions on earnings and control for observed characteristics such as gender, marital status, age, and ethnicity. For rural-to-urban migrants, they also control for the years since receiving an urban hukou. Their results show that the permanent rural-to-urban migrants who received their urban hukou before age 25 are economically well integrated in their destination city. Overall, this migrant group actually has higher earnings than local-born urban residents, probably because individuals who obtain an urban hukou before age 25 usually do so by being selected (through a highly selective process) to attend a higher education institution in the city, so more able persons comprised this group (Wu and Treiman 2004).

Several sociological studies have examined the effects of hukou status changes (or hukou mobility) on the labor market outcomes of permanent rural-to-urban migrants. For example, a recent paper by Zheng and $\mathrm{Wu}$ (2012) analyzes the earnings gap of urban local residents and permanent rural-to-urban migrants. They find that only the migrants who transferred their rural hukou to an urban hukou through a highly selective channel ${ }^{11}$ have higher earnings than local urban residents. Zhang and Treiman (2013) also separate permanent rural-to-urban migrants by the channels for transferring their hukou. Consistent with Zheng and $\mathrm{Wu}$ (2012), they find that permanent rural-to-urban migrants who obtain their urban hukou through a less selective process earn less than urban residents. They also find that permanent rural-to-urban migrants who transfer their hukou status after age 14 but before age 30 are more likely to attain a nonmanual labor job than urban residents. Similar to Deng and Gustafsson (2006), these migrants are likely to have obtained their urban hukou through admissions to higher education institutions and therefore have higher unobserved ability. Furthermore, few studies provide empirical evidence on the job mobility of rural migrants. Knight and Yueh (2004) compare temporary rural-to-urban migrants with urban 
residents and find a higher job turnover rate for the former group. Although the reform of state-owned enterprises in the late 1980s has increased the occupational mobility of urban workers, rural migrants have remained more mobile, even after controlling for demographic characteristics (Knight and Yueh 2004). On the contrary, Zhang (2010) argues that temporary migrants have longer job durations than local urban workers and only start to change jobs more often after they have stayed in their destination city for some time. However, due to data limitations, Zhang (2010) was not able to distinguish between temporary urban-to-urban migrants and temporary rural-to-urban migrants.

Therefore, our paper complements Gagnon et al.'s (2011) study by comparing permanent rural-to-urban migrants with urban-to-urban migrants to understand the assimilation of rural migrants into the urban labor market. Although the sample size of our data is smaller than Deng and Gustafsson's (2006), its retrospective information enables us to examine the occupational trajectories of permanent migrants. Another difference between the current paper and Deng and Gustafsson's (2006) study is that we limit our sample to individuals who migrated in the 1980s or later to exclude positively selected rural migrants who migrated for special policy reasons. ${ }^{12}$ A further contribution of this paper is the work on differences in mobility across migrant groups with different backgrounds: we distinguish between internal job mobility (i.e., within-work-unit job changes and promotions) and external job mobility (i.e., between-work-unit job changes and promotions) and discuss the variations and potential implications for both rural and urban migrants.

\section{Data}

The data used in this paper come from the CGSS (2003). The 2003 CGSS contains 5,900 urban households in more than 100 counties and districts in 26 provinces in China, as well as the cities of Beijing and Chongqing and four independently administered municipal districts 
(see more information in Bian and Li 2012). In addition to demographic information such as age, sex, education, family background, and household registration status (i.e., hukou), the 2003 CGSS provides each respondent's employment history from the first to the current job. The data offer details on the nature of employment, including three-digit occupation codes, management level, professional title, work-unit type, rank of the departmental supervisor for the work unit, job-related housing and medical benefits, and so forth.

Our main dependent variable is the occupational-prestige score, which we measure by the $z$-score of the average educational attainment of workers within each occupation normalized by the average educational attainment of all workers in the sample. ${ }^{13} \mathrm{We}$ also examine job mobility. We take advantage of rich information on work units and job ranks to capture upward job moves that are independent of occupational changes. Specifically, we count the number of job changes, both within and between work units, as well as moves to better jobs (i.e., jobs with higher social status and more positive work-unit environments). The construction of the variables is described in the appendix.

We constructed a panel data set from the retrospective information on hukou status changes, migration histories, education level, and job histories. Our sample consists of ruralto-urban migrants and urban-to-urban migrants who relocated to urban areas in the period from 1979 to 2003 and have complete information on the analyzed variables. ${ }^{14}$ Note that the CGSS only included urban residents in 2003. Consequently, most rural-to-urban migrants are permanent migrants who succeeded in obtaining an urban hukou at some point before 2003. Because these migrants have successfully settled in destination cities, they might be more positively selected than the population of rural-to-urban migrants, including those who have gone back to rural areas. The final sample contains 374 urban-to-urban migrants and 207 rural-to-urban migrants. 
Insert Table 1 about here

Panel A of table 1 provides demographic statistics for these two groups. Summing up the first, second, and later migration times, we have 374 urban-to-urban migration spells and 207 rural-to-urban migration spells in total. Although only one rural migrant experienced rural-to-urban migration twice, a non-negligible fraction of urban-to-urban migrants migrated more than once. The $t$ test shows that differences between the two groups are statistically significant in all demographic variables except for the year of migration and percentage of women. On average, the rural migrants in the sample are less educated than the urban migrants; specifically, about 65 percent of the rural migrants in the sample are at or below the middle-school level, whereas about 60 percent of the urban migrants are at the high school level or above. ${ }^{15}$ Additionally, the parents of the rural migrants are less educated than the parents of the urban migrants. The occupations of the rural migrants' fathers are less prestigious than those of urban migrants. Furthermore, the rural migrants themselves held less prestigious jobs prior to migration than the urban migrants. These variables indicate that the rural migrants have a lower socioeconomic background than the urban migrants. Finally, the average personal income in 2002 was 11,676 yuan for urban migrants and 8,134 yuan for rural migrants.

Panel B of table 1 presents the occupational-prestige scores in each year since migration. The negative scores (measured by the normalized mean education level) for ruralto-urban migrants reveal that they tend to take less prestigious jobs; specifically, their occupational-prestige scores are lower than the general population's average by around 27 to 33 percent of one standard deviation. The sample's urban migrants tend to take jobs with relatively high prestige — about 13 percent to 18 percent of one standard deviation higher than 
the population average. The table also shows little variation over time in the average occupational-prestige scores in the first ten years after migration for both rural and urban migrants.

Panel $\mathrm{C}$ of table 1 presents the number of job changes and upward moves within and between work units. A sizeable proportion of rural and urban migrants changed jobs and work units within the first ten years after their migration. In the sample, the rural-to-urban migrants are more mobile than the urban-to-urban migrants. Moreover, rural migrants are more likely to move to a better job in a different work unit than urban migrants.

Before carrying out the main analysis on the labor-market performance of the rural migrants and urban migrants, we compare their occupational-prestige scores with those of local urban residents of the same age and gender. ${ }^{16}$

Insert Figure 1 about here

Figure 1 illustrates how the difference in the occupational-prestige score of local urban residents evolves over time for rural and urban migrants. ${ }^{17} \mathrm{We}$ control for age, age-squared, and gender, and thus the graph represents the differences between migrants and local residents with the same age and gender. We see that the urban migrants are likely to hold jobs with more occupational prestige than the local urban residents, especially in the first few years after migration. This may be due to the fact that urban migrants have a higher education than urban residents who have never migrated. ${ }^{18}$ Other studies also find that urban migrants have a higher income level despite the limited choices of work sectors compared to the local residents (Gagnon et al, 2011). As expected, rural migrants hold jobs with much lower occupational prestige than the local urban residents. Section 5 investigates how much of this 
gap can be explained by differences in observed human capital, such as education and premigration job experience.

\section{Empirical Model}

To measure the gap between urban and rural migrants, we estimate the following regression: ${ }^{19}$

$Y_{i t}=\alpha+\beta R_{i}+\boldsymbol{\theta}^{\prime} \mathbf{X}_{\mathrm{it}}+\varepsilon_{i t}$,

where $y_{i t}$ represents the occupational-prestige score for individual $i$ in year $t$, and $R_{i}$ is a dummy variable for rural-to-urban migrant. $X_{i t}$ is a vector of control variables, to which we add variables gradually. $\varepsilon_{i t}$ represents the remaining error, which can be correlated within an individual. We cluster our standard errors at the individual level.

We begin by including only age, age-squared, and sex in $X_{i t}$ to examine the gap between urban and rural migrants without controlling for any differences in skill level. Then, we add the dummy variables for migrant's own educational background and observe how $\beta$ changes. Our hypothesis is that controlling for educational attainment will reduce the gap between the two types of migrants. To explore the role of family background in explaining the gap in the outcome variable, we add parents' years of schooling and father's occupational-prestige score from the year when the migrant was 18 years old. Finally, we add the occupational-prestige score of the last job prior to migration as a proxy for job experience accumulated before migration. As mentioned above, the quality of educational and job training received prior to migration for rural-to-urban migrants could be lower than urban-tourban migrants, which in turn could affect their assimilation in the destination city. Therefore, similar to the effect of education, our hypothesis is that controlling for the premigration occupational-prestige score will reduce the gap between the two groups of migrants. 
To allow $\beta$ and $\boldsymbol{\theta}$ to vary with years after migration, we estimate equation (1) separately for those in the first to third year, the fourth to sixth year, and the seventh to ninth year after migration. Furthermore, to explore the change of $\beta$ year by year, we estimate the following regression

$$
Y_{i t}=\alpha+\beta R_{i}+\sum_{k=2}^{9} \delta^{k} D^{k}{ }_{i t}+\sum_{k=2}^{9} \gamma^{k} D^{k}{ }_{i t} R_{i}+\boldsymbol{\theta}^{\prime} \mathbf{X}_{\mathrm{it}}+\varepsilon_{i t}
$$

and plot the gap in each year subsequent to migration. $\mathrm{D}^{k}{ }_{i t}$ is a dummy variable that takes the value of 1 if year $t$ is the $k^{\text {th }}$ year after migration for migrant $i . \beta+\gamma^{k}$ is the gap between rural and urban migrants in the $k^{\text {th }}$ year after migration for $k \geq 2$, and $\beta$ is the gap for $k=1$.

Furthermore, we estimate the following linear splines model as an alternative specification:

$$
Y_{i t}=\alpha+\beta_{0} R_{i}+\beta_{1}\left(R_{i} * k\right)+\beta_{2} \sum_{k=4}^{9} D^{k}{ }_{i t}\left(R_{i} * k\right)+\beta_{3} \sum_{k=7}^{9} D^{k}{ }_{i t}\left(R_{i} * k\right)+\phi k+\theta^{\prime} X_{i t}+\varepsilon_{i t} \text {. }
$$

The estimated coefficients $\beta_{0}, \beta_{1}, \beta_{2}$, and $\beta_{3}$ describe how the gap between rural-to-urban migrants and urban-to-urban migrants changes as they stay in the destination city. As an additional test, we estimate equations (1), (2), and (3) separately for migrants with different education levels. ${ }^{20}$

We further explore the job mobility of rural migrants compared to urban migrants by estimating an equation similar to equation (1), except that the sample is collapsed to the person level instead of the person-year level:

$$
Y_{i}=\alpha+\beta R_{i}+\theta^{\prime} X_{i}+\varepsilon_{i}
$$

The dependent variable Y represents the following four measures of job mobility, all measured in the first ten years after migration: (a) number of job changes, including job transfer within a work unit; (b) number of work-unit changes; (c) number of within-work-unit job promotions; and (d) number of upward moves between work units. 


\section{Findings}

\section{Occupational-Prestige Score}

\section{Insert Table 2 about here}

Table 2a presents the estimated coefficients of the dummy for rural migrants in equation (1). Column 1 includes age, age-squared, and sex in the covariates. Column 2 adds education dummies. Column 3 adds parent's education and father's occupational-prestige score. Column 4 adds the occupational-prestige score of the premigration job. Each row corresponds to a separate regression with a subsample divided by years since migration. First, we see that adding controls for education substantially narrowed the gap in occupationalprestige scores between rural and urban migrants. For example, in the first three years after migration, the gap is as large as 45 percent of one standard deviation of the scores when holding only age and gender constant, but the gap shrinks to 23 percent when controlling for education. On the other hand, controlling for parental background does not seem to narrow the gap after controlling for age, gender, and educational differences: rural migrants still hold less prestigious jobs than urban migrants, and the difference is statistically significant.

However, with controls for the occupational-prestige score of the last premigration job, the gap in postmigration occupational prestige between rural and urban migrants is no longer statistically significant. Therefore, the integration speed is similar for both rural-to-urban and urban-to-urban migrants who have the same preexisting characteristics. This finding implies that the observed gaps between rural and urban migrants are likely attributable to the differences in their human-capital accumulation prior to migration rather than discrimination against rural-to-urban migrants who otherwise have the same human capital as their urban-tourban counterparts. 
Figure 2 plots the estimated gap between rural-to-urban and urban-to-urban migrants in each year after migration from equation (2). The results confirm the observations from table 2 . Furthermore, the changes in the occupational-attainment gap between these two groups do not seem to change over time in any of the specifications. The stability of the gap over time suggests that something that determines the labor-market outcomes at the time of migration (in this case, the occupational-prestige score) continues to influence the occupational attainment of rural and urban migrants over their lifecycles. Such determinants also likely include educational attainment and job experience before migration because the gap between the two groups shrinks substantially after controlling for these variables. The results are qualitatively the same if we limit our samples to those who stayed at least nine years in the same city after migration or if we include a quadratic function of the year of migration as a control for potentially different selectivity into migration over time.

Table $2 \mathrm{~b}$ confirms the same observation from estimates of equation (3). All the coefficients on the interaction terms of rural dummy and years since migration are statistically insignificant, implying that the gap between rural and urban migrants do not change much over time. However, as we add controls, the estimated coefficient of rural dummy becomes smaller, and after controlling for premigration occupation, the gap disappears.

The gap between rural and urban migrants might vary by the educational background of migrants because premigration work experience may play different roles in the postmigration job market. Urban migrants have work experience in urban settings, and their premigration occupations could be more comparable to the ones in the destination city. 
Therefore, their accumulated skills, especially any job-specific skills, can be transferred more easily to the labor market destination compared to the skills of rural migrants. However, the required skills in the postmigration job market may differ by educational background: it is plausible that the more educated migrants are favored for their general skills, which have little to do with their urban or rural background. It is also possible that less educated migrants engage in occupations that do not require previously acquired skills; in that case, prior work experience should have little impact on their postmigration occupation. Furthermore, selection into higher education may be different. More educated migrants from rural areas may be more positively selected (i.e., have more ability) than their urban-migrant counterparts.

To explore this point, we run the regression separately for four subgroups, categorized by educational background: (a) primary school or less; (b) middle school; (c) regular high school; and (d) vocational education, professional school, and college. ${ }^{21}$ Table 3 (panels A to D) and figures 3A to 3D show the gaps in occupational-prestige scores between rural and urban migrants for these educational subgroups. ${ }^{22}$ Like table 2 and figure 2 , we gradually add explanatory variables, such as parental characteristics and the occupational-prestige scores of premigration jobs. Except for those with vocational high-school and college education, ruralto-urban migrants are entering jobs with a lower prestige score than urban-to-urban migrants. Yet, after controlling for the occupational-prestige score of premigration jobs, the gaps are no longer statistically significant, except for the least-educated group.

Insert Table 3 about here Insert Figures 3A to 3D about here 
In contrast, the gap is positive for migrants with more than a high-school education. This means that the rural migrants with more than a high-school education hold jobs with more occupational prestige than urban migrants with the same level of education. Panel D of table 3 shows that the effect is substantial in size: being a rural migrant is associated with a higher occupational-prestige score (by about 30 percent of one standard deviation), holding all other observed characteristics constant. This might imply that people in rural areas who pursue education beyond a high school degree are more positively selected than people in urban areas who go beyond high school, and thus rural migrants with more than a high school education have higher (unobservable) innate ability than urban migrants with the same observable characteristics. Therefore, the rural migrants are more likely to obtain an occupation with higher prestige than urban migrants with the same level of education.

\section{Job Mobility}

As indicated by panel $\mathrm{C}$ in table 1, rural-to-urban migrants tend to change jobs more frequently than urban-to-urban migrants. To examine whether such differences in job mobility can also be attributed to the differences in observed characteristics, we estimate equation (3) with the following dependent variables: (a) number of job changes, including job transfers within a work unit; (b) number of work-unit changes; (c) number of within-workunit job promotions; and (d) number of upward moves between work units. Because we define an upward change on the basis of work-unit type and job rank, the concept can capture some features associated with the job that are not reflected in the occupational-prestige score.

Table 4a presents the estimated coefficients of the dummy variable for rural-to-urban migrants. The first two rows show that rural-to-urban migrants are more mobile than urbanto-urban migrants, even after controlling for the occupational-prestige score of premigration jobs. This may be because, as Li (2008) argues, many rural migrants cannot afford to be 
unemployed for a long time. Another potential cause of the high mobility of rural migrants is their concentration in highly competitive, unskilled occupations, which tend to have less job security.

\section{Insert Table 4 about here}

The third row shows negative coefficients for the rural-migrants dummy variable. In particular, the findings reveal that rural-to-urban migrants are less likely than urban-to-urban immigrants to be promoted within work units, although the estimates are not statistically significant. In contrast, the fourth row shows that rural migrants are more likely to move to better jobs between work units. Table $4 \mathrm{~b}$ confirms the qualitatively the same results using a Poisson regression specification, except that we were not able to fit the model to the number of between-unit upward moves.

It is true that a part of this difference is spurious because rural migrants are more likely to change their job in general. However, this explanation does not account for all of the variation in the finding. A back-of-the-envelope calculation of the data (shown in panel $\mathrm{C}$ of table 1) suggests that the probability of a between-unit job change being an upward move is 19 percent for rural-to-urban migrants but just 10 percent for urban-to-urban migrants. Table 4 suggests that these differences are not likely to be attributed to the observed characteristics included in the fourth column. One possible explanation comes from Li's (2008) argument that rural migrants lack full information about the nature of their jobs and that rural migrants' first job in an urban labor market serves as a testing ground for their later progression to better jobs (with higher pay). 


\section{Concluding Remarks}

We utilize the retrospective information on employment and migration from the 2003 CGSS to analyze the labor-market performance of permanent rural-to-urban migrants and permanent urban migrants. We measure occupational attainment with an education-based index that reflects occupational prestige. Furthermore, we explore job mobility within and between work units.

The main finding of this paper is that the gap in occupational-prestige scores between rural-to-urban migrants and urban-to-urban migrants becomes very small and statistically insignificant after we control for observed characteristics including gender, educational attainment, family background, and the occupational-prestige scores of premigration jobs. Our results suggest that the observed inequality between permanent rural-to-urban and urbanto-urban migrants in occupational attainment can be attributed to differences in characteristics predetermined by the time of migration. In fact, after controlling for the characteristics of premigration jobs, the gap between rural and urban migrants is no longer statistically significant, and in some cases the effect even becomes positive (although not significant). Because the occupational-prestige score of the last job prior to migration is a proxy for job experience accumulated before migration, the job before migrants relocated to the urban destination seems to play an important role for their future integration with urban natives. Therefore, it is important to investigate what types of education or training would be helpful for rural children if they decide to relocate to urban areas after schooling. In particular, with the rapid technological advancement of urban jobs, it is imperative to understand whether the skills that current rural workers possess are transferable to their new urban positions. One way to facilitate transferability might be, for example, to enhance the rural education experience by strengthening the partnership between rural schools and urban 
communities so that rural children can explore real urban settings before they migrate for urban jobs.

Although the analysis of occupational-prestige scores reveals a similar speed of integration into the urban labor market for permanent rural-to-urban and urban-to-urban migrants within the first ten years after migration, we find that rural-to-urban migrants experience higher job mobility. In the present data, urban-to-urban migrants are more likely to move upward in the same work unit by, for instance, obtaining more job autonomy (e.g., increased supervisory role at the job) or receiving more medical and housing benefits. However, rural-to-urban migrants tend to have fewer opportunities than urban-to-urban migrants for job promotion within work units, although the finding is not statistically significant. These different paths of upward job mobility might be the cause of the higher level of job mobility of rural-to-urban migrants, although it might also be the case that rural migrants suffer from job insecurity. It is beyond the scope of this paper to pin down where this difference comes from; nonetheless, it is plausible that rural migrants try to achieve better job outcomes by continually seeking opportunities outside their current workplace.

Finally, China is quickly granting more permanent urban household registrations to rural-to-urban migrants (Xie 2010; Zheng and Wu 2012). The relaxation of the country's hukou policy is intended to settle most members of the floating population in the cities after removing the hurdles created by the hukou system (Zhu 2007). On the one hand, a better understanding of permanent rural-to-urban migrants and their occupational attainment will shed light on how hukou policy might affect the labor-market performance of the floating population. On the other hand, permanent urban migrants also constitute a large proportion of the internal migrants in China (Gagnon et al, 2011). Certainly, our analyses are mostly descriptive and are subject to the selectivity of migrants. Still, the findings offer important information to understand the assimilation process of these permanent migrants, a group that 
has received relatively little attention in the current literature. Examining how permanent rural and urban migrants are faring in the urban labor market will be an important topic for future research. For instance, studies should begin to identify and understand the heterogeneity of assimilation patterns across migrants who have different sociodemographic backgrounds or who obtained their permanent urban hukou through different channels (Zhang and Treiman 2013; Zheng and $\mathrm{Wu} 2012$ ). 


\section{Appendix}

\section{Construction of Job Mobility Variables}

The number of job changes and work-unit changes can be derived directly from the survey data. Below we describe how we define job promotions within the same work unit and between different units.

By definition, a job promotion is the permanent movement of a staff member from a position in one job class to a position in another job class of increased responsibility or complexity of duties and in a higher salary range. To compare the skill requirements, responsibilities, and relative pay scales and job benefits within and between different work units, we will briefly summarize the characteristics of each work unit and some description on the China's economic reform prior to 2003.

First, we divide employment into two groups based on eight work-unit types in our data:

\section{Group I}

1. Party, government, or government agency or office

2. State-owned institution (SOI)

Group II

3. State-owned enterprise (SOE)

4. Collectively owned institution or enterprise

5. Individually operated enterprise

6. Private institution or enterprise

7. Foreign-investment enterprise(FIE)

8. Others $^{23}$

Group I is state owned, not for profit, and has the highest job security and benefits of any group. The administrative rank only applies to this group and is a very important determinant of one's wage level and other benefits. A job promotion occurs if an individual moves to a work unit with a higher rank. Within Group I, work-unit-type 1 (party government, etc.) ranks higher than the SOI.

For within-work-unit change in work-unit types 1 and 2, the second determinant is the rank of administration is, including from low to high: (a) no rank; (b) below vice-section-level; (c) vicesection-level ; (d) section-level; (e) vice-department-level (f) department level; (g) vice-bureau-level; and $(\mathrm{h})$ bureau-level and higher. The supervision department level is the third determinant of job promotion and the fourth determinant would be housing and medical benefits.

Compared to Group I, the work units in Group II have more autonomy and are for-profit. The administrative rank does not apply to these work units in general. It is worth noting that the stateowned enterprises ${ }^{24}$ are a partial result of the economic reform of the state-owned sector. Employees in SOEs are assumed to enjoy a higher wage benefit including bonuses, higher job security, and a lower risk of company bankruptcy. Thus, we define upward mobility as occurring when the individual transfers from a non-SOE to an SOE that is under the supervision of a department either at a central or a provincial level of government. 
Upward job mobility among SOEs is determined by the level of supervisory of a department, including from high to low: (a) central, (b) prefecture, (c) district or county, (d) street or township, (e) neighbourhood or village committee, and (f) other.

There is one exception to these classifications: if a person moved from any work units in Group II to an FIE and the management level at the previous job is considered to be lower than the management level at the FIE (the new job), we define the mobility as upward as well. Here management level is a proxy for skills.

For all non-SOEs, job security is the highest in collectively owned institutions, where the decisions of hiring and firing reside among the workers' union. Additionally, job security is relatively equal among most of the workers. Therefore, any job changes from other non-SOEs to collectively owned institutions or enterprises are considered to be upward mobility. One exception to this classification is that we consider moves to individually operated enterprises, private institutions or enterprises, or FIEs to be upward mobility if and only if the supervisory level is higher at the new job.

Finally, upward mobility is considered to occur for occupational changes from farming or the army to any other type of work. 


\section{References}

Autor, David, Lawrence Katz, and Melissa Kearney. 2006. "The Polarization of the U.S. Labor Market." In NBER working paper, No.11986. . 2008. "Trends in U.S. Wage Inequality: Revising the Revisionists." The Review of Economics and Statistics 90(2):300-323.

Bian, Yanjie, and Lulu Li. 2012. "The Chinese General Social Survey (2003-2008): Sample Designs and Data Evaluation." Chinese Sociological Review 45(1):70-97.

de Brauw, Alan, and John Giles. 2006. "Migrant Opportunity and the Educational Attainment of Youth in Rural China." IZA Discussion Paper, No.2326.

Cai, Fang , and Dewen Wang. 2007. "Impacts of Internal Migration on Economic Growth and Urban Development in China." Mimeo, Institute of Population and Labor Economics, CASS. Retrieved June 8, 2010.

Chan, Kam wing, and Will Bukingham. 2008. "Is China Abolishing the Hukou System?" The China Quarterly 195:582-606.

Chan, Kam wing, and Li Zhang. 1999. "The Hukou System and Rural-Urban Migration in China: Process and Changes." The China Quarterly 160:818-855.

Démurger, Sylvie, Marc Gurgand, Li Shi, and Yue Ximing. 2009. "Migrants as Second-Class Workers in Urban China? A Decomposition Analysis." Journal of Comparative Economics 37(4):610-628.

Deng, Quheng, and Björn Anders Gustafsson. 2006. “China’s Lesser Known Migrants.” IZA Discussion Paper, No.2152.

Fan, Cindy. 2002a. "The Elite, the Natives, and the Outsiders: Migration and Labor Market Segmentation in Urban China." Annals of the Association of American Geogrphers 92(1):103-124.

- 2002b. " Migration, Hukou, and the Chinese City. In Memo.Retrieved March 5, 2012.

Gagnon, Jason, Theodora Xenogiani, and Chunbing Xing. 2011. "Are All Migrants Really Worse off in Rrban Labour Markets? New Empirical Evidence from China." IZA Discussion Paper, No.6268.

Ganzeboom, Harry B., Paul M. De Graaf, and Donald J. Treiman. 1992. “A Standard International Socio-Economic Index of Occupational Status.” Social Science Research 21:1-56.

Ganzeboom, Harry B., and Donald J. Treiman. 1996. "Internationally Comparable Measures of Occupational Status for the 1988 International Standard Classification of Occupations." Social Science Research 25:201-239.

Hao, Lingxin. 2012. "Cumulative Causation of Rural Migration and Initial Peri-Urbanization in China." Chinese Sociological Review, 44 (3): 6-33.

Knight, John, and Linda Yueh. 2004. "Job Mobility of Residents and Migrants in Urban China." Journal of Comparative Economics 32(4):637-660.

Kondo, Ayako, and Dongshu Ou. 2010. "In Search of a Better Life: the Occupational Attainment of Rural and Urban Migrants in China." ISER Discussion Paper, No. 0793: Institute of Social and Economic Research, Osaka University.

Li, Shi. 2008. "Rural Migrant Workers in China: Scenario, Challenges and Public Policy." International Labour Office, Policy Integration and Statistics Department. Working Paper No.89.

Liang, Zai, and Zhongdong Ma. 2004. "China's Floating Population: New Evidence from the 2000 Census." Population and Development Review 30(3):467-488.

Liu, Zhiqiang. 2005. "Institution and Inequality: the Hukou System in China." Journal of Comparative Economics 33(1):133-157.

Lu, Zhigang, and Shunfeng Song. 2006. "Rural-Urban Migration and Wage Determination: the Case of Tianjin, China." China Economic Review 17:337-345. 
Meng, Xin , and Junsen Zhang. 2001. "The Two-Tier Labor Market in Urban China:

Occupational Segregation and Wage Differentials between Urban Residents and Rural Migrants in Shanghai." Journal of Comparative Economics 29(3):485-504.

Meng, Xin, and Frances Perkins. 1998. "Wage Determination Differences between Chinese State and Non-State Firms." Asian Economic Journal 12(3):295-316.

Wang, Xiaozhou, R.S. Oropesa, and Glenn Firebaugh. 2009. "Permanent Migrants in China: Hukou Origin and Economic Integration." In Population Association of America 2009 Annual Meeting.Retrieved March 5, 2012.

Wu, Xiaogang, and Donald Treiman. 2004. "The Household Registration System and Social Stratification in China: 1955-1996.” Demography 42(2):363-384.

_. 2007. "Inequality and Equality Under Chinese Socialism: the Hukou System and Intergenerational Occupational Mobility." American Journal of Sociology 113(2):415445.

Xie, Yu. 2010. "Speed Up Reform of Household Registration, Say Newspapers." China Daily.Retrieved March 5, 2012.

Zhang, Huafeng. 2010. “The Hukou System's Constraints on Migrant Workers' Job Mobility in Chinese Cities." China Economic Review 21(1):51-64.

Zhang, Zhuoni, and Donald Treiman. 2013. "Social Origins, Hukou Conversion, and The Wellbeing of Urban Residents in Contemporary China." Social Science Research 42(1):71-89.

Zhang, Zhuoni, and Xiaogang Wu. 2012. "Registration Status,Occupational Segregation and Rural Migrants in Urban China." The Hong Kong University of Science and Technology, Hong Kong SAR.

Zhao, Yaohui, and Qiming Liu. 1997. "Zhongguo Chengxiang Qianyi De Lishi Yanjiu: 19491985, Zhongguo Renkou Kexue.” China Population Science 2.Retrieved March 5, 2012.

Zhao, Zhong. 2005. "Migration, Labor Market Flexibility, and Wage Determination in China: A Review." Developing Economies 43(2):285-312.

Zheng, Bingdao, and Xiaogang Wu. 2012. "Household Registration, Urban Status Attainment, and Social Stratification in Urban China." The Hong Kong University of Science and Technology, Hong Kong SAR.

Zhu, Yu. 2007. "China's Floating Population and their Settlement Intention in the Cities: beyond the Hukou Reform." Habitat International 31(1):65-76. 
Table 1. Summary Statistics

A. Predetermined characteristics

\begin{tabular}{|c|c|c|c|}
\hline & $\begin{array}{c}\text { Urban } \\
\text { Migrants }\end{array}$ & $\begin{array}{c}\text { Rural } \\
\text { Migrants } \\
\end{array}$ & \\
\hline Sample size & 374 & 207 & \\
\hline 1st migration & 321 & 206 & \\
\hline 2nd migration & 47 & 1 & \\
\hline 3rd migration & 6 & 0 & \\
\hline Means of explanatory variables & & & $t$-test stat \\
\hline Year of migration & 1990.3 & 1990.5 & 0.29 \\
\hline Age at the time of migration & 33.2 & 31.7 & $-2.08 * *$ \\
\hline$\%$ Female & $52.9 \%$ & $53.8 \%$ & 0.23 \\
\hline Years of schooling & 11.5 & 9.6 & $-7.57 * * *$ \\
\hline$\%$ primary school or less & $9.0 \%$ & $27.9 \%$ & \\
\hline$\%$ middle school & $30.9 \%$ & $37.0 \%$ & \\
\hline$\%$ high school & $27.0 \%$ & $22.1 \%$ & \\
\hline $\begin{array}{l}\% \text { vocational education, professional school and } \\
\text { college }\end{array}$ & $33.0 \%$ & $13.0 \%$ & \\
\hline Father's years of schooling & 7.5 & 4.8 & $-6.91 * * *$ \\
\hline Mother's years of schooling & 4.5 & 2.4 & $-5.79 * * *$ \\
\hline $\begin{array}{l}\text { Occupational-prestige score of father's job in the } \\
\text { year when the respondent was } 18\end{array}$ & -0.10 & -1.29 & $-14.27 * * *$ \\
\hline $\begin{array}{l}\text { Occupational-prestige score of the job held in the } \\
\text { year prior to migration }\end{array}$ & 0.12 & -0.60 & $-9.75 * * *$ \\
\hline Income in 2002 (yuan) & 11675.85 & 8133.77 & $-2.76 * * *$ \\
\hline
\end{tabular}

B. Occupational-prestige score by years since migration

\begin{tabular}{lcccccc}
\hline \multirow{2}{*}{$\begin{array}{l}\text { Year since } \\
\text { migration }\end{array}$} & \multicolumn{3}{c}{ Urban migrants } & \multicolumn{3}{c}{ Rural migrants } \\
\cline { 2 - 7 } & Mean & $\begin{array}{c}\text { Standard } \\
\text { Deviation }\end{array}$ & Obs. & Mean & $\begin{array}{c}\text { Standard } \\
\text { Deviation }\end{array}$ & Obs. \\
\hline 1 & 0.18 & 0.69 & 417 & -0.31 & 0.83 & 189 \\
2 & 0.15 & 0.69 & 399 & -0.32 & 0.82 & 179 \\
3 & 0.15 & 0.70 & 374 & -0.28 & 0.82 & 179 \\
4 & 0.14 & 0.68 & 345 & -0.27 & 0.81 & 171 \\
5 & 0.16 & 0.69 & 327 & -0.29 & 0.81 & 158 \\
6 & 0.17 & 0.70 & 305 & -0.31 & 0.80 & 148 \\
7 & 0.16 & 0.71 & 280 & -0.30 & 0.81 & 137 \\
8 & 0.17 & 0.69 & 258 & -0.31 & 0.83 & 132 \\
9 & 0.16 & 0.70 & 232 & -0.28 & 0.83 & 123 \\
10 & 0.13 & 0.70 & 215 & -0.33 & 0.82 & 118 \\
\hline
\end{tabular}


C. Job mobility in the first $\mathbf{1 0}$ year after migration

Number of observations: urban migrants 256, rural migrants 141

\begin{tabular}{rccccccccc}
\hline & \multicolumn{2}{c}{$\begin{array}{c}\text { Number of job } \\
\text { changes }\end{array}$} & \multicolumn{2}{c}{$\begin{array}{c}\text { Number of work-unit } \\
\text { changes }\end{array}$} & \multicolumn{2}{c}{$\begin{array}{c}\text { Number of within } \\
\text { unit promotion }\end{array}$} & \multicolumn{2}{c}{$\begin{array}{c}\text { Number of across } \\
\text { unit upward move }\end{array}$} \\
\cline { 2 - 9 } of changes & urban & rural & urban & rural & urban & rural & urban & rural \\
\hline 0 & $55.9 \%$ & $38.3 \%$ & $84.0 \%$ & $63.8 \%$ & $92.6 \%$ & $95.7 \%$ & $98.1 \%$ & $91.5 \%$ \\
1 & $35.6 \%$ & $42.6 \%$ & $14.1 \%$ & $29.1 \%$ & $5.5 \%$ & $3.6 \%$ & $2.0 \%$ & $8.5 \%$ \\
2 & $6.3 \%$ & $12.8 \%$ & $1.6 \%$ & $5.0 \%$ & $2.0 \%$ & $0.7 \%$ & & \\
3 & $2.0 \%$ & $5.0 \%$ & $0.4 \%$ & $2.1 \%$ & & & & \\
4 & $0.0 \%$ & $1.4 \%$ & & & & & & \\
6 & $0.4 \%$ & $0.0 \%$ & & & & & & \\
\hline
\end{tabular}


Table 2. Gaps in the Occupational-Prestige Score between Rural-to-Urban and Urban-to-Urban Migrants

a. Coefficients of the rural-migrant dummy variable in equation (1)

\begin{tabular}{|c|c|c|c|c|}
\hline Control variables: & $\begin{array}{l}\text { Age and sex } \\
\text { only }\end{array}$ & $\begin{array}{l}\text { (1) plus own } \\
\text { education }\end{array}$ & $\begin{array}{c}\text { (3) } \\
\text { (2) plus } \\
\text { parents' } \\
\text { education and } \\
\text { occupation }\end{array}$ & $\begin{array}{l}\text { (4) } \\
\text { (3) plus the } \\
\text { prestige score } \\
\text { of the } \\
\text { premigration } \\
\text { job }\end{array}$ \\
\hline $\begin{array}{l}\text { 1-3 years after migration } \\
\text { (sample size: } 1,737 \text { ) }\end{array}$ & $\begin{array}{c}-0.449 * * * \\
(0.070) \\
\end{array}$ & $\begin{array}{c}-0.235^{* * * *} \\
(0.066) \\
\end{array}$ & $\begin{array}{c}-0.223^{* * * *} \\
(0.069) \\
\end{array}$ & $\begin{array}{l}-0.005 \\
(0.054) \\
\end{array}$ \\
\hline $\begin{array}{l}\text { 4-6 years after migration } \\
\text { (sample size: } 1,454 \text { ) }\end{array}$ & $\begin{array}{c}-0.427 * * * \\
(0.075)\end{array}$ & $\begin{array}{c}-0.220 * * * \\
(0.069)\end{array}$ & $\begin{array}{c}-0.197 * * * \\
(0.075)\end{array}$ & $\begin{array}{l}-0.009 \\
(0.066)\end{array}$ \\
\hline $\begin{array}{l}\text { 7-9 years after migration } \\
\text { (sample size: } 1,162 \text { ) }\end{array}$ & $\begin{array}{c}-0.435^{* * *} \\
(0.082) \\
\end{array}$ & $\begin{array}{c}-0.217 * * * \\
(0.073) \\
\end{array}$ & $\begin{array}{c}-0.196^{* * *} \\
(0.079) \\
\end{array}$ & $\begin{array}{l}-0.025 \\
(0.072) \\
\end{array}$ \\
\hline
\end{tabular}

b. Coefficients of linear splines $(\beta)$ in equation (3)

\begin{tabular}{|c|c|c|c|c|}
\hline Sample: & $\begin{array}{l}\text { Age and sex } \\
\text { only }\end{array}$ & $\begin{array}{l}\text { (1) plus own } \\
\text { education }\end{array}$ & $\begin{array}{c}\text { (3) } \\
\text { (2) plus } \\
\text { parents' } \\
\text { education and } \\
\text { occupation }\end{array}$ & $\begin{array}{l}\text { (4) } \\
\text { (3) plus the } \\
\text { prestige score } \\
\text { of the } \\
\text { premigration } \\
\text { job }\end{array}$ \\
\hline $\begin{array}{l}\text { Rural dummy } \\
\left(\beta_{0}\right)\end{array}$ & $\begin{array}{c}-0.453 * * * \\
(0.076)\end{array}$ & $\begin{array}{c}-0.217 * * * \\
(0.074)\end{array}$ & $\begin{array}{c}-0.200 * * * \\
(0.077)\end{array}$ & $\begin{array}{l}-0.024 \\
(0.062)\end{array}$ \\
\hline $\begin{array}{l}\text { Years since migration* } \mathrm{R} \\
\left(\beta_{1}\right)\end{array}$ & $\begin{array}{c}0.005 \\
(0.015) \\
\end{array}$ & $\begin{array}{l}-0.001 \\
(0.013) \\
\end{array}$ & $\begin{array}{l}-0.001 \\
(0.013) \\
\end{array}$ & $\begin{array}{c}0.001 \\
(0.013) \\
\end{array}$ \\
\hline $\begin{array}{l}\text { Years since migration* } \mathrm{R} \\
* \mathrm{yr} \_ \text {mig } \geq 4\left(\beta_{2}\right)\end{array}$ & $\begin{array}{c}0.000 \\
(0.008)\end{array}$ & $\begin{array}{c}0.000 \\
(0.007)\end{array}$ & $\begin{array}{c}0.000 \\
(0.007)\end{array}$ & $\begin{array}{c}0.001 \\
(0.006)\end{array}$ \\
\hline $\begin{array}{l}\text { Years since migration* } \mathrm{R} \\
* \mathrm{yr} \_ \text {mig } \geq 7\left(\beta_{3}\right)\end{array}$ & $\begin{array}{l}-0.003 \\
(0.006)\end{array}$ & $\begin{array}{l}-0.001 \\
(0.006)\end{array}$ & $\begin{array}{l}-0.001 \\
(0.006)\end{array}$ & $\begin{array}{c}0.001 \\
(0.006)\end{array}$ \\
\hline
\end{tabular}

Note: OLS regression with repeated observations from the same individuals. Standard errors are in brackets and are clustered by individual ID. 
Table 3. Gaps in the Occupational-Prestige Score between Rural-to-Urban and Urban-to-Urban Migrants, by Education

A. Primary school or less

a. Coefficients of the rural-migrant dummy variable in equation (1)

\begin{tabular}{|c|c|c|c|}
\hline & (1) & (2) & (3) \\
\hline Sample: & $\begin{array}{l}\text { Age, sex, and } \\
\text { primary school } \\
\text { dummy }\end{array}$ & $\begin{array}{l}\text { (1) plus parents' } \\
\text { education and } \\
\text { occupation }\end{array}$ & $\begin{array}{l}\text { (2) plus the prestige } \\
\text { score of the } \\
\text { premigration job }\end{array}$ \\
\hline $\begin{array}{l}\text { 1-3 years after migration } \\
\text { (sample size: } 265 \text { ) }\end{array}$ & $\begin{array}{c}-0.610 * * * \\
(0.139) \\
\end{array}$ & $\begin{array}{c}-0.549 * * * \\
(0.168) \\
\end{array}$ & $\begin{array}{l}-0.269 \\
(0.169) \\
\end{array}$ \\
\hline $\begin{array}{l}\text { 4-6 years after migration } \\
\text { (sample size: } 220 \text { ) }\end{array}$ & $\begin{array}{c}-0.611 * * * \\
(0.147)\end{array}$ & $\begin{array}{c}-0.534 * * * \\
(0.189)\end{array}$ & $\begin{array}{l}-0.372^{*} \\
(0.203)\end{array}$ \\
\hline $\begin{array}{l}\text { 7-9 years after migration } \\
\text { (sample size: 189) }\end{array}$ & $\begin{array}{c}-0.568 * * * \\
(0.169) \\
\end{array}$ & $\begin{array}{c}-0.493 * * \\
(0.204) \\
\end{array}$ & $\begin{array}{l}-0.341 \\
(0.233) \\
\end{array}$ \\
\hline \multicolumn{4}{|c|}{ b. Coefficients of linear splines $(\beta)$ in equation (3) } \\
\hline Sample : & $\begin{array}{c}\text { (1) } \\
\text { Age, sex, and } \\
\text { primary school } \\
\text { dummy }\end{array}$ & $\begin{array}{l}\text { (2) } \\
\text { (1) plus parents' } \\
\text { education and } \\
\text { occupation }\end{array}$ & $\begin{array}{l}\text { (3) } \\
\text { (2) plus the prestige } \\
\text { score of the } \\
\text { premigration job }\end{array}$ \\
\hline $\begin{array}{l}\text { Rural dummy } \\
\left(\beta_{0}\right)\end{array}$ & $\begin{array}{c}-0.652 * * * \\
(0.140)\end{array}$ & $\begin{array}{c}-0.595^{* * *} \\
(0.169)\end{array}$ & $\begin{array}{c}-0.382 * * \\
(0.174)\end{array}$ \\
\hline $\begin{array}{l}\text { Years since migration* } \mathrm{R} \\
\left(\beta_{1}\right)\end{array}$ & $\begin{array}{c}0.02 \\
(0.023)\end{array}$ & $\begin{array}{c}0.021 \\
(0.023)\end{array}$ & $\begin{array}{c}0.015 \\
(0.020)\end{array}$ \\
\hline $\begin{array}{l}\text { Years since migration* } \mathrm{R} \\
* \mathrm{yr} \_ \text {mig } \geq 4\left(\beta_{2}\right)\end{array}$ & $\begin{array}{l}-0.005 \\
(0.015)\end{array}$ & $\begin{array}{l}-0.005 \\
(0.015)\end{array}$ & $\begin{array}{l}-0.004 \\
(0.014)\end{array}$ \\
\hline $\begin{array}{l}\text { Years since migration* } \mathrm{R} \\
* \mathrm{yr} \_ \text {mig } \geq 7\left(\beta_{3}\right)\end{array}$ & $\begin{array}{c}0.002 \\
(0.007)\end{array}$ & $\begin{array}{c}0.002 \\
(0.007)\end{array}$ & $\begin{array}{c}0.004 \\
(0.006)\end{array}$ \\
\hline
\end{tabular}

\section{B. Middle school}

a. Coefficients of the rural-migrant dummy variable in equation (1)

\begin{tabular}{lccc}
\hline Control variables: & $(1)$ & $\begin{array}{c}(2) \\
\text { (1) plus parents' } \\
\text { education and } \\
\text { occupation }\end{array}$ & $\begin{array}{c}\text { (2) plus the prestige } \\
\text { score of the } \\
\text { premigration job }\end{array}$ \\
\hline 1-3 years after migration & Age and sex & -0.105 & 0.071 \\
(sample size: 571$)$ & $-0.193^{*}$ & $(0.110)$ & $(0.081)$ \\
\hline 4-6 years after migration & $-0.110)$ & -0.116 & 0.037 \\
(sample size: 457 ) & $(0.126)$ & $(0.128)$ & $(0.103)$ \\
\hline 7-9 years after migration & $-0.254^{* *}$ & $-0.222^{*}$ & -0.053 \\
(sample size: 359$)$ & $(0.124)$ & $(0.126)$ & $(0.099)$ \\
\hline
\end{tabular}


b. Coefficients of linear splines $(\beta)$ in equation (3)

\begin{tabular}{lccc}
\hline Control variables: & $\begin{array}{c}(1) \\
\text { Age, sex, and } \\
\text { primary school } \\
\text { dummy }\end{array}$ & $\begin{array}{c}(2) \\
\text { (1) plus parents' } \\
\text { education and } \\
\text { occupation }\end{array}$ & $\begin{array}{c}\text { (2) plus the prestige } \\
\text { score of the } \\
\text { premigration job }\end{array}$ \\
\hline Rural dummy & -0.117 & -0.04 & 0.103 \\
$\left(\beta_{0}\right)$ & $(0.127)$ & $(0.126)$ & $(0.095)$ \\
\hline Years since migration*R & -0.031 & -0.034 & -0.03 \\
$\left(\beta_{1}\right)$ & $(0.024)$ & $(0.024)$ & $(0.023)$ \\
\hline Years since migration*R & 0.012 & 0.012 & 0.012 \\
*yr_mig $\geq 4\left(\beta_{2}\right)$ & $(0.010)$ & $(0.010)$ & $(0.009)$ \\
\hline Years since migration*R & 0.001 & 0.001 & 0.003 \\
$*$ yr_mig $\geq 7\left(\beta_{3}\right)$ & $(0.014)$ & $(0.014)$ & $(0.013)$ \\
\hline
\end{tabular}

\section{High school}

a. Coefficients of the rural-migrant dummy variable in equation (1)

\begin{tabular}{lccc}
\hline Control variables: & Age and sex & $\begin{array}{c}(2) \\
\text { (1) plus parents' } \\
\text { education and } \\
\text { occupation }\end{array}$ & $\begin{array}{c}\text { (2) plus the prestige } \\
\text { score of the } \\
\text { premigration job }\end{array}$ \\
\hline 1-3 years after migration & $-0.295^{* *}$ & $-0.299^{* *}$ & -0.122 \\
(sample size: 435$)$ & $(0.128)$ & $(0.145)$ & $(0.123)$ \\
\hline 4-6 years after migration & $-0.277^{* *}$ & -0.225 & -0.101 \\
(sample size: 361$)$ & $(0.131)$ & $(0.143)$ & $(0.151)$ \\
\hline 7-9 years after migration & $-0.257^{*}$ & -0.244 & -0.157 \\
(sample size: 275$)$ & $(0.150)$ & $(0.168)$ & $(0.185)$ \\
\hline
\end{tabular}

b. Coefficients of linear splines $(\beta)$ in equation (3)

\begin{tabular}{lccc}
\hline Control variables: & $\begin{array}{c}(1) \\
\text { Age, sex, and } \\
\text { primary school } \\
\text { dummy }\end{array}$ & $\begin{array}{c}(2) \\
\text { (1) plus parents' } \\
\text { education and } \\
\text { occupation }\end{array}$ & $\begin{array}{c}\text { (2) plus the prestige } \\
\text { score of the } \\
\text { premigration job }\end{array}$ \\
\hline Rural dummy & $-0.308^{*}$ & $-0.287^{*}$ & -0.136 \\
$\left(\beta_{0}\right)$ & $(0.158)$ & $(0.162)$ & $(0.133)$ \\
\hline Years since migration*R & 0.008 & 0.01 & 0.008 \\
$\left(\beta_{1}\right)$ & $(0.038)$ & $(0.037)$ & $(0.035)$ \\
\hline Years since migration*R & -0.003 & -0.004 & -0.007 \\
$*$ yr_mig $\geq 4\left(\beta_{2}\right)$ & $(0.018)$ & $(0.018)$ & $(0.016)$ \\
\hline Years since migration*R & 0.001 & 0 & -0.003 \\
$*$ yr_mig $\geq 7\left(\beta_{3}\right)$ & $(0.011)$ & $(0.011)$ & $(0.009)$ \\
\hline
\end{tabular}


D. Vocational education, professional school and college

a. Coefficients of the rural-migrant dummy variable in equation (1)

\begin{tabular}{lccc}
\hline Control variables: & $\begin{array}{c}(1) \\
\text { Age, sex, and } \\
\text { dummies for } \\
\text { educational } \\
\text { attainment }\end{array}$ & $\begin{array}{c}(1) \\
\text { (1) plus parents' } \\
\text { education and } \\
\text { occupation }\end{array}$ & $\begin{array}{c}\text { (2) plus the prestige } \\
\text { score of the } \\
\text { premigration job }\end{array}$ \\
\hline 1-3 years after migration & 0.173 & 0.130 & $0.232^{*}$ \\
(sample size: 466$)$ & $(0.136)$ & $(0.140)$ & $(0.123)$ \\
\hline 4-6 years after migration & 0.173 & 0.131 & $0.321^{* * *}$ \\
(sample size: 416$)$ & $(0.126)$ & $(0.138)$ & $(0.121)$ \\
\hline 7-9 years after migration & $0.251^{*}$ & 0.231 & $0.406^{* * *}$ \\
(sample size: 339$)$ & $(0.134)$ & $(0.149)$ & $(0.133)$ \\
\hline
\end{tabular}

b. Coefficients of linear splines $(\beta)$ in equation (3)

(1)

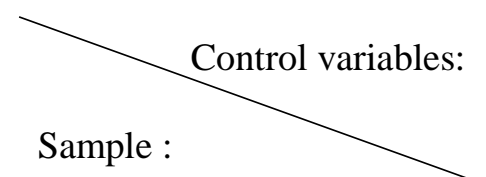

Age, sex, and primary school dummy
(2)

(1) plus parents' education and occupation
(3)

(2) plus the prestige score of the premigration job

\begin{tabular}{lccc}
\hline Rural dummy & 0.142 & 0.111 & 0.136 \\
$\left(\beta_{0}\right)$ & $(0.173)$ & $(0.176)$ & $(0.158)$ \\
\hline Years since migration* $\mathrm{R}$ & 0.023 & 0.02 & $0.047^{*}$ \\
$\left(\beta_{1}\right)$ & $(0.036)$ & $(0.037)$ & $(0.028)$ \\
\hline Years since migration*R & -0.011 & -0.01 & -0.009 \\
$* \mathrm{yr}$ mig $\geq 4\left(\beta_{2}\right)$ & $(0.015)$ & $(0.015)$ & $(0.014)$ \\
\hline Years since migration*R & -0.006 & -0.005 & -0.006 \\
$* \mathrm{yr} \_$mig $\geq 7\left(\beta_{3}\right)$ & $(0.011)$ & $(0.011)$ & $(0.009)$ \\
\hline
\end{tabular}

Note: OLS regression with repeated observations of the same individuals. Standard errors are in brackets and are clustered by individual ID. 
Table 4. Gaps in Job Mobility in the First 10 Years after Migration between Rural-to-Urban and Urban-to-Urban Migrants

a. Linear OLS regressions

Coefficients of the rural-migrant dummy variable; sample size $=397$

(1) (2) (3)

(4)

\begin{tabular}{lcccc}
\multicolumn{1}{c}{ Control variables: } & $\begin{array}{c}\text { Age and } \\
\text { sex only }\end{array}$ & $\begin{array}{c}\text { (1) plus own } \\
\text { education }\end{array}$ & $\begin{array}{c}\text { (2) plus parents' } \\
\text { education and } \\
\text { occupation }\end{array}$ & $\begin{array}{c}\text { (3) plus the prestige } \\
\text { score of the } \\
\text { premigration job }\end{array}$ \\
variablent : & $0.401^{* * *}$ & $0.320^{* * *}$ & $0.380^{* * *}$ & $0.332^{* * *}$ \\
\hline Number of job changes & $(0.105)$ & $(0.100)$ & $(0.097)$ & $(0.091)$ \\
\hline Number of work-unit changes & $0.257^{* * *}$ & $0.243^{* * *}$ & $0.274 * * *$ & $0.263^{* * *}$ \\
& $(0.076)$ & $(0.073)$ & $(0.067)$ & $(0.065)$ \\
\hline Number of within-unit promotions & -0.027 & -0.031 & -0.033 & -0.049 \\
& $(0.028)$ & $(0.028)$ & $(0.032)$ & $(0.030)$ \\
\hline Number of between-unit upward moves & $0.055^{* *}$ & $0.052^{*}$ & $0.068^{* * *}$ & $0.066^{* * *}$ \\
& $(0.027)$ & $(0.027)$ & $(0.025)$ & $(0.025)$ \\
\hline
\end{tabular}

Note: OLS regression with repeated observations of the same individuals. Standard errors are in brackets and are clustered by individual ID.

b. Poisson regressions

Coefficients of the rural-migrant dummy variable; sample size $=397$

(1)

(2)

(3)

(4)

\begin{tabular}{lcccc}
\hline Control variables: & $\begin{array}{c}\text { Age and } \\
\text { sex only }\end{array}$ & $\begin{array}{c}\text { (1) plus own } \\
\text { education }\end{array}$ & $\begin{array}{c}\text { (2) plus parents' } \\
\text { education and } \\
\text { occupation }\end{array}$ & $\begin{array}{c}\text { (3) plus the prestige } \\
\text { score of the } \\
\text { premigration job }\end{array}$ \\
\hline variables : & $0.467 * * *$ & $0.546^{* * *}$ & $0.450^{* * *}$ & $0.537 * * *$ \\
Number of job changes & $(0.122)$ & $(0.134)$ & $(0.134)$ & $(0.130)$ \\
\hline Number of work-unit changes & $0.874 * * *$ & $0.829 * * *$ & $0.797 * * *$ & $0.907 * * *$ \\
& $(0.200)$ & $(0.232)$ & $(0.233)$ & $(0.205)$ \\
\hline Number of within-unit promotions & -0.706 & -0.343 & -0.394 & -0.443 \\
& $(0.458)$ & $(0.395)$ & $(0.407)$ & $(0.475)$ \\
\hline
\end{tabular}

Note: Poisson regression with repeated observations of the same individuals. Standard errors are in brackets and are clustered by individual ID. The result for the number of between-unit upward changes is not reported because we were not able to get convergence. 
Table A1. Reasons for Migration, by Rural and Urban status, Education, and Year of Migration (\%)

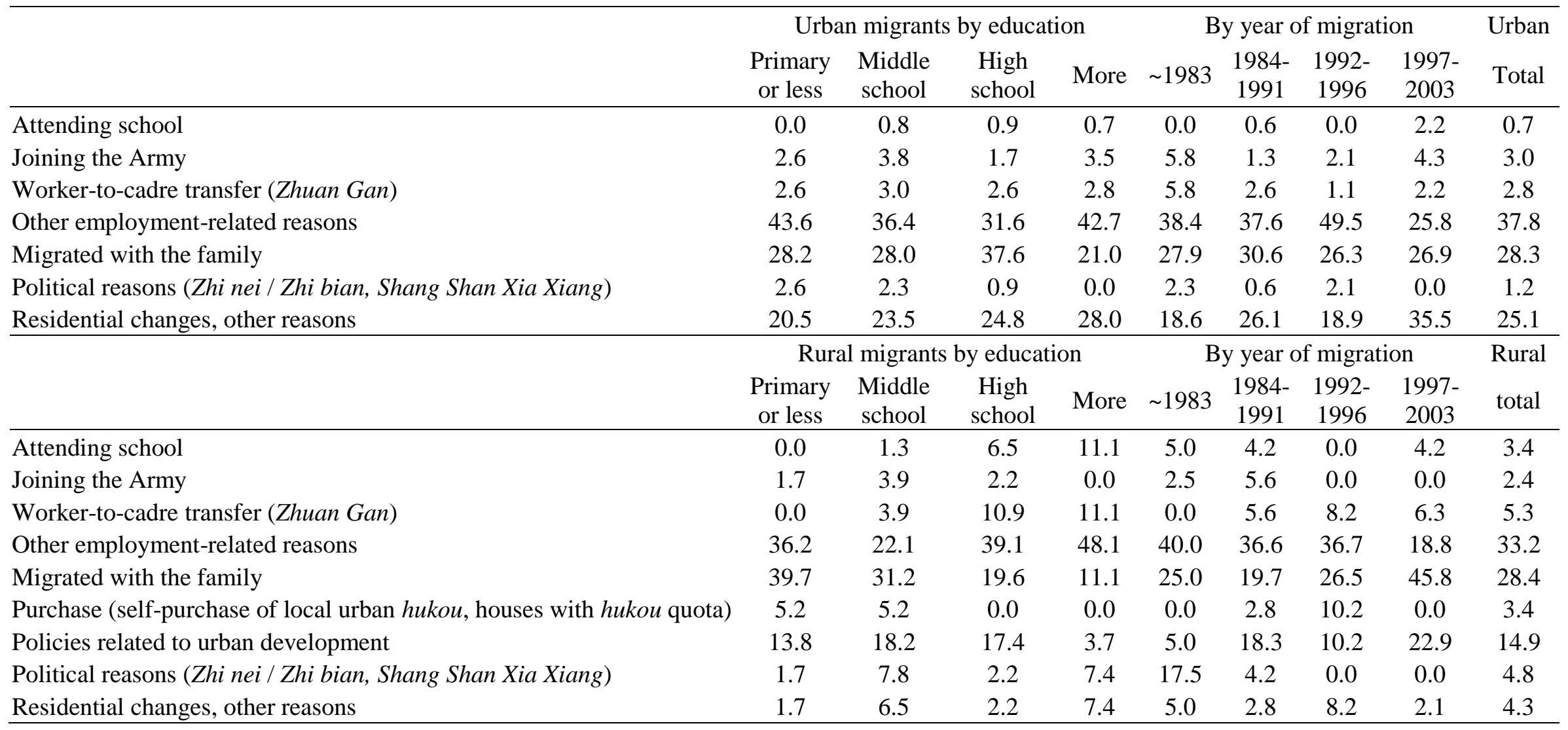


Table A3. Gaps in Income in 2002 between Rural-to-Urban and Urban-to-urban Migrants Coefficients of the rural-migrant dummy variable

Control variables:
(1)

(2)

Age and (1) plus own sex only education
(3)

(2) plus parents education and occupation

Sample:

$-0.224 * *-0.224 * *$

$-0.173^{*}$

(3) plus the prestige score of the

All migrants in the sample

$(0.088) \quad(0.088)$

Year of migration $\geq 1993$

$-0.071$

$(0.100)$ premigration job

(sample size: 160)

(0.141) $\quad(0.141)$

$-0.273^{* *} \quad-0.273^{* *}$

$-0.023$

$-0.113$

Year of migration $<1993$

$(0.124)$

$(0.124)$

$(0.150)$

(sample size: 190)

Note: OLS regression with repeated observations of the same individuals. Standard errors are in

$-0.235$

$(0.142)$

$-0.017$

$(0.154)$ brackets and are clustered by individual ID.

Table A2. Distribution of Educational Background, by Rural and Urban Status and Year of Migration

\section{A. Urban Migrants}

1979-1983 1984-1991 1992-1996 1997-2003 Total

All urban migrants including those dropped due to missing variables

\begin{tabular}{lcccccc}
\hline Primary school or less & 20.9 & 10.8 & 3.2 & 1.1 & 9.1 & 15.7 \\
Middle school & 34.9 & 31.9 & 33.7 & 21.5 & 30.6 & 28.5 \\
High school & 20.9 & 28.7 & 26.3 & 31.2 & 27.2 & 28.2 \\
More & 23.3 & 28.7 & 36.8 & 46.2 & 33.2 & 27.6 \\
\hline
\end{tabular}

B. Rural Migrants

\begin{tabular}{lcccccc}
\hline & & & & & & $\begin{array}{c}\text { All rural migrants } \\
\text { including those } \\
\text { dropped due to } \\
\text { missing variables }\end{array}$ \\
\hline Primary school or less & 35.0 & 29.6 & 22.5 & 25.0 & 27.9 & 32.1 \\
Middle school & 40.0 & 33.8 & 40.8 & 35.4 & 37.0 & 37.1 \\
High school & 17.5 & 23.9 & 20.4 & 25.0 & 22.1 & 25.0 \\
More & 7.5 & 12.7 & 16.3 & 14.6 & 13.0 & 5.8 \\
\hline
\end{tabular}




\section{Figure Captions:}

Figure 1: Differences in Occupational-Prestige Score from Local Local-Born Workers Notes:

(a)The $\mathrm{Y}$-axis represents the gap of occupational-prestige scores between migrants and local urban residents. The $\mathrm{X}$-axis represents the years since migration.

(b) The independent variables included are age, age squared, and a dummy variable for female.

Figure 2: Changes in the Occupational-Prestige-Score Gaps between Rural-to-Urban and Urban-toUrban Migrants over Time

Notes:

(a)The $\mathrm{Y}$-axis is the gap in occupational-prestige scores between rural-to-urban and urban-to-urban migrants. The $\mathrm{X}$-axis represents the length of the migration spell.

(b) Model 1 includes age, age squared, and a dummy variable for female in the RHS. Model 2 builds on model 1 by adding dummies for the level of education. Model 3 adds father's education, mother's education, and an occupational-prestige score for father's occupation. Model 4 adds the occupationalprestige score of the respondent's premigration job.

(c) The sample is limited to those with no missing information in the full models.

Figure 3a: Changes in the Occupational-Prestige-Score Gaps between Rural-to-Urban and Urban-toUrban Migrants over Time, Primary School and Below

Figure 3b: Changes in the Occupational-Prestige-Score Gaps between Rural-to-Urban and Urban-toUrban Migrants over Time, Middle School

Figure 3c: Changes in the Occupational-Prestige-Score Gaps between Rural-to-Urban and Urban-toUrban Migrants over Time, High School

Figure 3d: Changes in the Occupational-Prestige-Score Gaps between Rural-to-Urban and Urban-toUrban Migrants over Time, Vocational Education, Professional School, and College

Notes:

(a)The $\mathrm{Y}$-axis is the gap in occupational-prestige scores between rural-to-urban and urban-to-urban migrants. The $\mathrm{X}$-axis represents the length of the migration spell.

(b) Model 1 includes age, age-squared, and a dummy variable for female in the RHS (and dummies for vocational and professional schools for 3d). Model 2 builds on model 1 by adding father's education, mother's education, and an occupational-prestige score for father's occupation. Model 3 adds the occupational-prestige score of the respondent's premigration job.

(c) The sample is limited to those with no missing information in the full models. 
${ }^{1}$ According to Liang and Ma (2004, Table 4), of the 79,053 total internal migrants in China in 2000, 58,835 were temporary migrants (both urban and rural).

${ }^{2}$ See Chan and Buckingham (2008), Chan and Zhang (1999), and Fan (2002a, 2002b) for a detailed review of the hukou system and related policy. Most of the existing literature has used data that only allowed researchers to identify hukou type. The data used in our paper include precise information on where the hukou was registered as well as the origin of the migrant.

${ }^{3}$ Change in hukou status is referred to as hukou mobility or hukou conversion in the sociological literature.

${ }^{4}$ Zheng and $\mathrm{Wu}(2012)$ argue that obtaining an urban hukou through a highly selective process, such as going to urban schools, could lead to high selectivity for permanent rural-to-urban migrants. The unobserved high ability could potentially explain their better labor market performance. By including observations with premigration work experience, our sample of rural-to-urban migrants could be less selective. As table A1 shows, less than 1 percent of the urban migrants and 4 percent of the rural migrants migrated to the destination city to attend school. Although employment-related reasons can also lead to selectivity (Zheng and $\mathrm{Wu} 2012$ ), table A1 shows that the proportions of urban-to-urban and rural-tourban migrants who move for employment reasons are very similar.

${ }^{5}$ We create an index of occupational prestige, ranked by the mean of educational attainment within an occupation. In particular, the index is the standardized z-score based on the mean level of education for each occupation. Details are described in Kondo and $\mathrm{Ou}$ (2010). This measure has been used often in job-polarization and wage-inequality studies (e.g., Autor, Katz, and Kearney $(2006,2008)$ ). An alternative method would be to use the international socioeconomic index (ISEI; Ganzeboom et al. 1992, Ganzeboom and Trieman 1996). The results are not included in this paper but they are qualitatively the same as the results reported here. We thank Xiaogang Wu for sharing the coding strategy for mapping the occupational classification in the CGSS to the ISEI to make this robustness check possible.

${ }^{6}$ This group is also known as the floating population (liu dong ren kou).

${ }^{7}$ For example, Meng and Zhang (2001) find that education increases the probability of rural-to-urban migrants who obtain a white-collar job. A recent study by Demurger et al. (2009) finds that differences by job sector are not as important as the differences driven by educational attainment.

${ }^{8}$ However, permanent rural-to-urban migrants are highly advantaged relative to the average permanent urban resident due to positive selection (Wu and Treiman 2004). Zhang and Trieman (2013) also find that permanent rural-to-urban migrants who transfer their hukou after age 14 are happier than urban residents despite having lower average earnings, poorer health outcomes, and lower occupational status.

${ }^{9}$ Admittedly, selection into migration may be very different for rural residents than for urban residents, and the observed difference between these two groups might be driven by differences in selectivity. We cannot fully control for this selectivity, but we have tried to account for changes in selectivity over time; specifically, controlling for the year of migration does not significantly alter the results.

${ }^{10}$ See also Zhao (2005) for a survey of research papers on rural-to-urban migration issues in China.

${ }^{11}$ In general, obtaining an urban hukou for education or work reasons involves a very selective process because only highly skilled people are admitted to higher education 
institutions or given urban jobs. There are other ways of obtaining an urban hukou, but they do not involve a highly selective process (e.g., as a result of a policy on urban development or to reunite with family_. For discussion on the channels of hukou status transfers, see Wu and Treiman (2004, 2007), Zheng and Wu (2012), Chan and Buckingham (2008), and Chan and Zhang (1999).

${ }^{12}$ For example, job transfer was a typical reason for state-planned migration before the hukou reform period; in this process, highly educated rural workers were selected for urban government jobs (Chan and Bukingham 2008). Consequently, the permanent migrants in Deng and Gustafsson's (2006) study are more educated than the permanent migrants in our sample and therefore might be subject to positive selection bias. Table A1 shows the distribution of migration reasons for rural and urban migrants by educational level and birth cohort.

${ }^{13}$ As a robustness check, we examine the $z$-scores of the residuals from regressing the years of education on a polynomial function of birth year to remove the potential bias of prestige scores due to variations in educational attainment across different birth cohorts (see the data appendix in Kondo and $\mathrm{Ou} 2010$ ).

${ }^{14}$ We limit our sample to rural-to-urban migrants and urban-to-urban migrants who migrated into the city in the period from 1979 to 2003. This time window helps to exclude large migrations due to special policy reasons such as "up to the mountain, down to the village." Rural-to-urban migrants are migrants who reported a rural-to-urban hukou transfer (nong-zhuan-fei) and who were holding an urban hukou in the year of 2003. Urban-to-urban migrants are migrants who were born with an urban hukou. Finally, we restrict our sample to those who have valid information for all variables included in the regression analysis. Such variables include educational background, parental information, and jobs held in the year prior to the migration. Consequently, this limits our sample to those who had a job both before and after migration. The numbers of remaining individuals at each step of data construction are presented in Kondo and Ou (2010).

${ }^{15}$ This ratio is even higher than that of urban residents who have never migrated, which is about 50 percent. Our sample of rural migrants is on average less educated than the data used by Deng and Gustafsson (2006). Deng and Gustafsson's (2006) sample has an average of eleven years of schooling, and the figure for each educational level for rural migrants is 8 percent for primary school or below, 26 percent for middle school, 35 percent for high school, and 32 percent for college or higher. The corresponding figures for the urban-born sample are 4 percent, 27percent, 43 percent, and 26 percent, respectively. Because their sample is much older than ours, it is likely to include individuals who had migrated to cities before the hukou relaxation policy. Older samples may cause selection bias because early hukou policy was so strict that only highly skilled and highly educated individuals tended to migrate, usually in response to government efforts to relocate personnel. We limit our data to individuals who migrated in the 1980s or later to avoid this potential selection bias. Table A2 provides more details on the education distribution of rural and urban permanent migration by the year of migration.

${ }^{16}$ Ideally, we would like to compare the scores between migrants and local residents in the same geographical area. However, the data set does not contain such information.

${ }^{17}$ The estimation equation is $Y_{i t}=\alpha+\sum_{k=1}^{10} \delta^{k} D^{k}{ }_{i t} U_{i}+\sum_{k=1}^{10} \gamma^{k} D^{k}{ }_{i t} R_{i}+\boldsymbol{\theta}^{\prime} \mathbf{X}_{\mathrm{it}}+\varepsilon_{i t}$, where $\mathrm{k}=$ $1,2, \ldots 9, \mathrm{D}^{k}{ }_{i t}$ takes a value of 1 if year $t$ is the $k^{\text {th }}$ year after migration for migrant $i$. $\mathrm{D}^{10}{ }_{i t}$ takes a value of 1 if ten or more years have passed since the migration as of year $t . \mathrm{U}_{\mathrm{i}}$ is a dummy for urban migrants, $R_{i}$ is a dummy for rural migrants. $X$ is a vector of control variables that includes age, age squared, and gender. $\gamma^{k}$ is the gap between rural migrants and native-born 
urban residents in the $k^{\text {th }}$ year after migration. $\delta^{k}$ is the gap between urban migrants and native-born urban residents in the $k^{\text {th }}$ year after migration.

${ }^{18}$ Among the CGSS sample, about 20 percent of urban residents who have never migrated since 1978 have a primary school education or less, whereas only 9 percent of the urban migrants do. The proportion of those who have a high school education or more is about 50 percent for urban nonmigrants and 60 percent for urban migrants. This difference is not attributable to the differences in generation because the average age is similar between the two groups. Furthermore, the composition of educational background of our sample looks similar to Gagnon et al.'s (2011) data: urban migrants (26 percent college or higher, 36 percent high school, 32 percent middle school, and 6 percent primary school), and urban residents ( 22 percent, 31 percent, 37 percent, and 10 percent, respectively).

${ }^{19} \mathrm{We}$ estimate simple repeated ordinary least squares regressions even though we have panel data because more than half of the migrants have migrated only once.

${ }^{20}$ To explore the comparability of our occupational prestige measure and earnings, we also examine the gap in personal income in 2002 between urban and rural migrants. The equation we estimate is the same as equation (3), except that the dependent variable is personal income in 2002 and the sample is limited to those who had a nonzero income in 2002. The results for personal income (table A3) are consistent with the basic observations from the occupational-prestige scores (table 2). In particular, the income gap becomes smaller and statistically insignificant when we control for the prestige scores of premigration jobs and other explanatory variables. In addition, we use earnings in 2002 to gauge the economic impact of one unit of change in the occupational prestige score (although information on income or earnings prior to 2002 is not available). A regression of earnings in 2002 on the occupational-prestige score in the same year indicates that a one-point increase in the occupational-prestige score corresponds to a 41-percent increase in annual earnings (24\% if the worker's own sex and educational back ground is controlled).

${ }^{21}$ Vocational and professional schools both offer career-oriented education, which is quite different from regular high school, which focuses on academic study. Therefore we separate these two groups from regular high school. At the same time, there are only eight rural migrants who have a college-level education. Thus we are not able to separate college graduates from vocational and professional schools.

${ }^{22}$ Significant flows of rural migrants have moved to peri-urban areas, such as small towns (Hao 2012). We also conducted an analysis by dividing the sample by the size of the destination city, including small towns, counties, and other large cities. The results are presented in the working paper version of this study (see Kondo and Ou 2010, table A4). We do not observe statistically significant differences for those who migrated to small towns; however, the gap between rural migrants and urban migrants remains negative for those who migrated to counties and other large cities (without controlling for the occupational-prestige score of the premigration job). The gap gradually reduces along with the length of stay in large cities. The gap decreases even further and becomes positive for migrants who moved to large cities once we control for the premigration occupational-prestige score, although these trends are not statistically significant.

${ }^{23}$ Very few cases in our data are categorized as "other." We treat them as the lowest rank in terms of job preference, so any move from the category of "other" to the other seven types of work units would be treated as upward mobility.

${ }^{24}$ See, for example, Meng and Perkins (1998) for a definition of and more information about SOEs. 